LSID urn:1sid:zoobank.org:pub:DE48A4F5-EF56-4B41-98F1-D9E0BA5B7BD7

\title{
On a new species of the genus Tetrabezzia KIEFFER, 1917 from West Bengal, India, with a key to world species (Diptera: Ceratopogonidae)
}

\author{
POULAMI SAHA, NILADRI HAZRA* \\ Entomology Research Unit, Department of Zoology, University of Burdwan, \\ Burdwan, 713104, India
}

\begin{abstract}
Adults of a new species of the genus Tetrabezzia KIEFFER, 1917 are described and illustrated from India. Two species of this genus were previously known from the subcontinent and the Oriental region. Keys to the adult males and females of the world species are also provided.
\end{abstract}

KEY WORDS: Biting midge, Heteromyiini, Orient.

\section{INTRODUCTION}

The Old-World genus Tetrabezzia KIEFFER, 1917, with six previously named species (BORKENT, 2016), is one of the smaller genera of the family Ceratopogonidae. It was established by KIEFFER (1917) based on the type species, Dibezzia spinigera (KIEFFER, 1914) and currently includes four Afrotropical species (Guinea, Nigeria, Mozambique and Madagascar) and two from India (CLASTRIER 1982). So far, out of six known species, adult males of two species (Tetrabezzia africana CLASTRIER, 1982 and T. pictipennis (KIEFFER, 1913)) have been recorded. The large midges of the genus (females have a wing length of 2.88-4.70 mm) are one of the least studied genera in the tribe Heteromyiini. The common diagnostic features of both sexes of Tetrabezzia are: horizontally projecting anterior

\footnotetext{
* Corresponding author: hazra.niladri@gmail.com
} 
tubercle on the scutum; wing with patches of dark pigmentation, costa long, one radial cell; legs long and slender, especially hind pair; fore femur with a few small ventral spines distally; hind femur with distinct subapical swelling; abdomen long and petiolate. The adult female has: greatly elongated hind tarsus; fourth tarsomere of fore and mid legs with bifid spinose lobes; fifth tarsomere of hind leg extremely slender without ventral armature; claws greatly elongated with a long inner basal tooth, especially long and slender on hind leg; two functional spermathecae and one rudimentary. Adult male has: subtriangular aedeagus and parameres fused basally with clavate apices (DE MEILLON \& WIRTH 1991).

The present paper describes adults of both sexes of a new species of the genus from India. Keys to the adult females of seven and the males of three world species are also provided.

\section{MATERIAL AND METHODS}

Adults of both sexes were caught using both a miniature Centre for Disease Control (CDC) light trap with an $8 \mathrm{~W}$ white tube light and an open type light trap with a $15 \mathrm{~W}$ white bulb. Microslide mounts of the material were made following WIRTH \& MARSTON (1968). The illustrations were produced using compound microscopes (Olympus, Model HB, India and Wild Leitz GMBH, Portugal) in combination with a camera lucida. The photographs were taken both with a trinocular compound microscope (Wild Leitz GMBH) and a Stereo Zoom trinocular microscope (Olympus make, model SZX16, Japan). The morphology and terminology of adults follow BORKENT et al. (2009). Measurements are expressed in millimetres $(\mathrm{mm})$ with the ranges in front of the parentheses and the mean value within them when the number of specimens is more than two.

The type specimens, at present in the Entomological Collections of the Department of Zoology, University of Burdwan (India), will be deposited in the National Zoological Collections of India, and the Natural History Museum, London in due course.

Abbreviations used: AR - antennal ratio; $\mathrm{SCh}$ - sensilla chaetica; $\mathrm{P} / \mathrm{H}$ - proboscis to head ratio; PR - palpal ratio; CR - costal ratio; WL - wing length; WW - wing width; TRn - tarsal ratio; BUENTD - Burdwan University Entomology Division; NZCI - National Zoological Collections of India; NHML - Natural History Museum, London. 

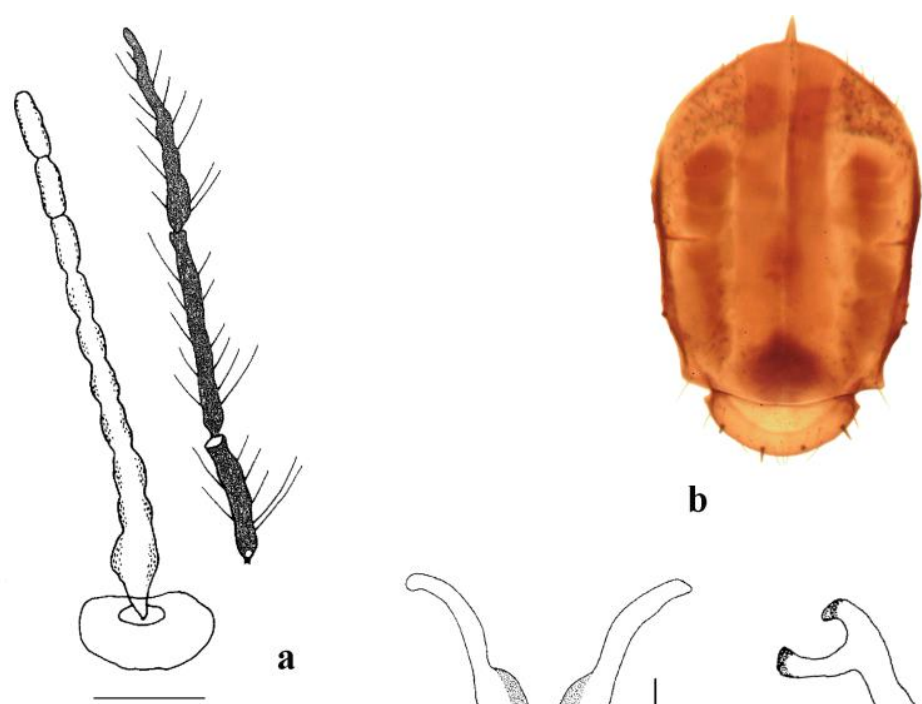

b

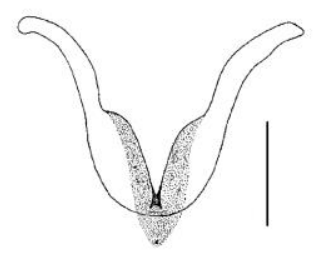

c
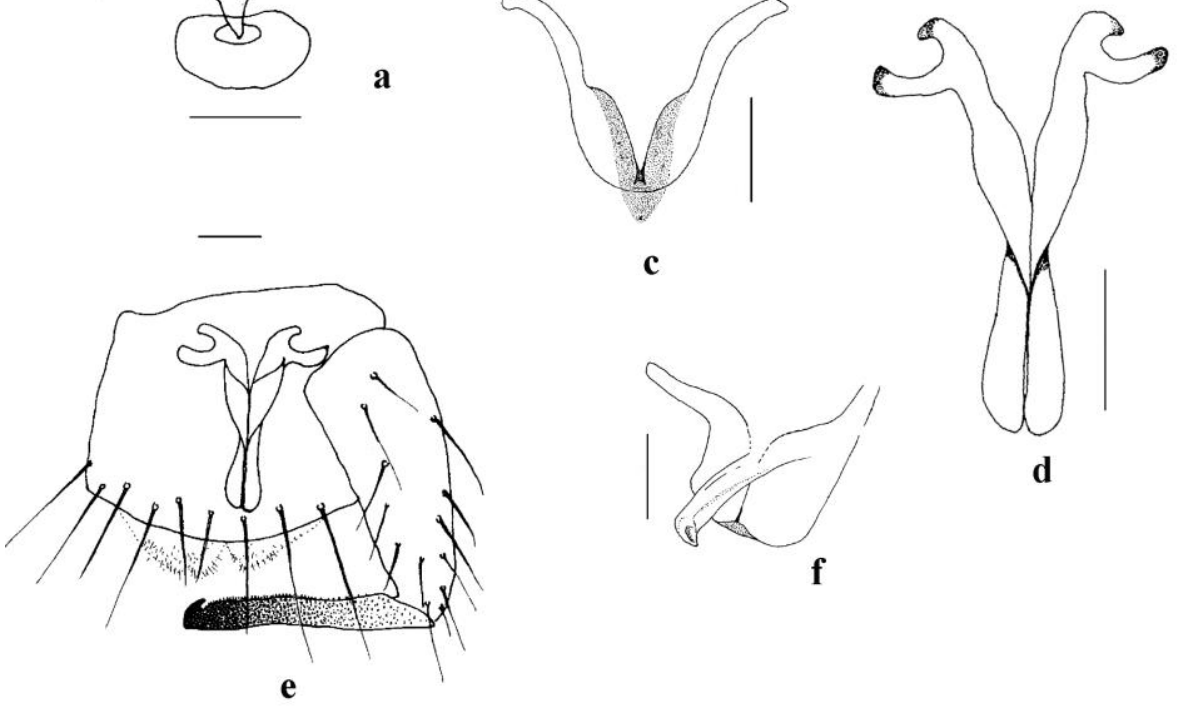

d

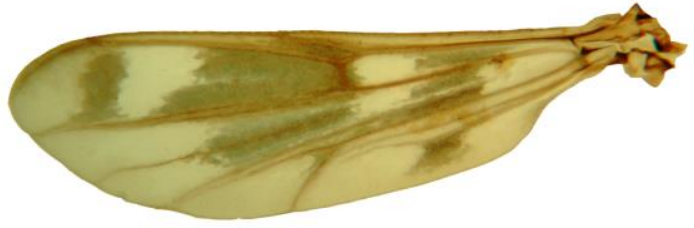

g

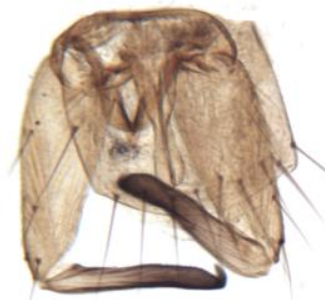

h

Fig. 1. Adult male of Tetrabezzia dasguptai sp. n.: a, Antenna; b, Thorax (photograph); c, Aedeagus (dorsal view); d. Parameres; e, Genitalia; f, Aedeagus (lateral view); g, Wing (photograph); h, Genitalia (photograph); (Scale bar: Figure a $-0.18 \mathrm{~mm}$; Figures c \& d-0.03 mm; Figure e - 0.04mm; Figure f $-0.05 \mathrm{~mm}$ ). 

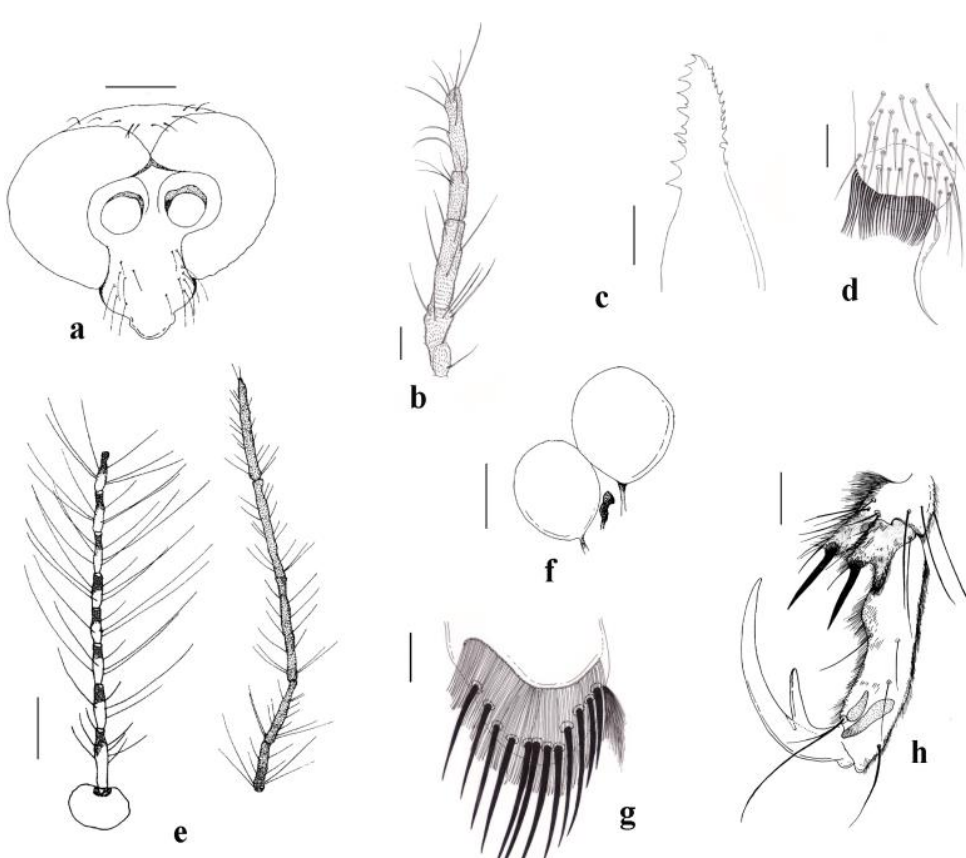

b
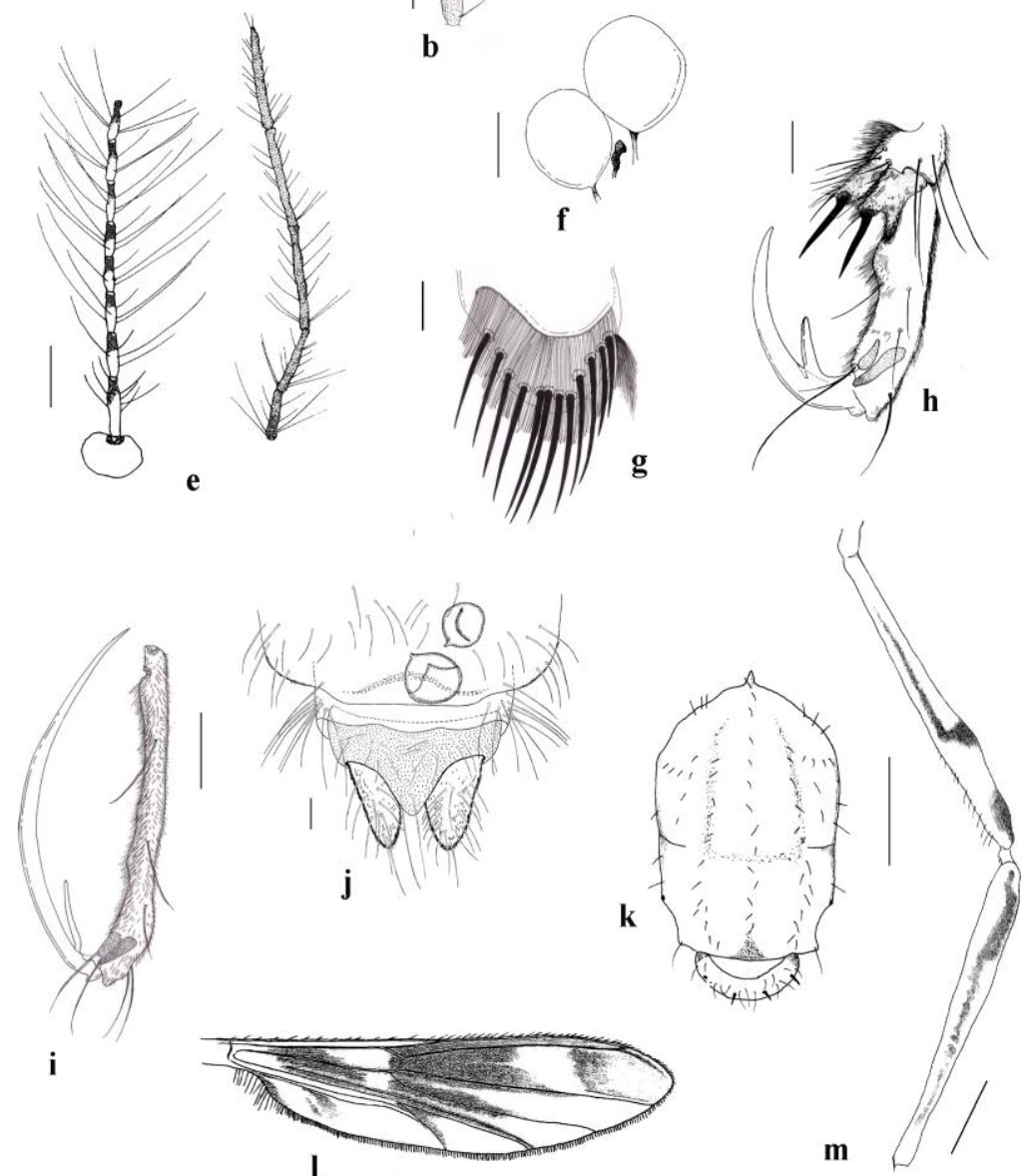

Fig. 2. Adult female of Tetrabezzia dasguptai sp. n.: a, Head; b, Maxillary palp (dorsal view); c, Mandible (dorsal view); d, fore tibial comb and apical spine; e, Antenna; f, Spermathecae; g, Hind tibial comb; h, Tarsomeres IV-V with claw of fore leg; $\mathrm{i}$, Tarsomere V with claw of hind leg; j, Female genitalia (ventral view); k, Thorax; 1, Wing; m, Hind femur and tibia; (Scale bar: Figure a - 0.11 mm; Figures b, j, $1-0.04$ mm; Figures c, d, g - 0.05 mm; Figures e \& i - 0.18 mm; Figures f \& h -0.03 mm; Figures $\mathrm{k} \& \mathrm{~m}-0.33 \mathrm{~mm}$ ). 


\section{RESULTS}

\section{Tetrabezzia dasguptai sp. $\mathbf{n}$.}

(Figs 1, 2)

\section{Type material}

Holotype male, labelled 'Holotype Tetrabezzia dasguptai SAHA \& HAZRA, India, West Bengal, Uttar Dinajpur, Panjipara (2608'26.7"N, 8801'09.8"E), 03.XI.2016, Coll. P. SAHA' (NZCI). Paratypes 5 males, 4 females same data as holotype (1 female, NZCI; 4 males, 2 females, BUENTD; 1 male, 1 female, NHML).

\section{Diagnosis}

The only Tetrabezzia with the following characters: dorso-median dark patch present at posterior end of scutum; costa and $\mathrm{R}_{3}$ meet near wing tip; a brown streak parallel to wing margin extending between apex of $\mathrm{R}_{3}$ and wing tip; mid and hind femora and tibiae with brown bands and streak in both sexes. Adult male: aedeagus with anterior concavity, strongly curved blunt ended basal arch, pointed posteromedial process; parameres abutting basally but not fused, bifid posterolaterally; tarsomere 5 of all legs uniformly brown.

\section{Description}

Male $(n=6)$

Head. Reddish yellow. Eyes bare, weakly contiguous. Antennal plume well developed, flagellomeres I-V fused (Fig 1a), XI-XIII long and dark, AR 1.5-1.6 (1.5). Palpus dark, PR 2.2-4.0 (3.2). P/H 1.17 (1.1-1.3).

Thorax (Fig 1b). Reddish yellowish brown. Scutum with distinct vittae, pruinose with antepronotals 5-6 on each side, acrostichals 12-14, uniserial restricted to anterior twothirds, dorsocentrals 20-22 on one side, mostly uniserial, prealars 5-6 on each side, supraalars 2 on each side, a strong spine (0.05-0.07 (0.06) $\mathrm{mm}$ long) on anterior margin of supraalar region, horizontally projecting strong, pointed anterior tubercle $0.05-0.07(0.056) \mathrm{mm}$ long, $0.02 \mathrm{~mm}$ wide basally, dorso-median dark patch present at posterior end; scutellum reddish yellow with 4 evenly spaced strong spines (0.04-0.07 (0.05) $\mathrm{mm}$ long) and 10-14 spines scattered along outer margin, postscutellum reddish yellow medially, brownish laterally.

Wing (Fig 1g). Most of membrane faintly greyish white, with pattern of darkly mottled pigmentation scattered over membrane; costa and $\mathrm{R}_{3}$ meet near wing tip, costa not extending beyond $\mathrm{R}_{3}$, a brown streak parallel to wing margin arising from apex of $\mathrm{R}_{3}$ and ending near wing tip; radial cell elongate, 0.75-0.82 (0.79) $\mathrm{mm}$ long; microtrichia abundant, 
very fine, shorter than in female. WL 1.44-1.64 (1.55) $\mathrm{mm}$; WW 0.48-0.52 (0.5) $\mathrm{mm}$; CR 0.82-0.87 (0.84). Haltere pale yellowish.

Legs. Dark reddish yellow. Foreleg coxa, trochanter, femur similarly pigmented; femur armed with 2-4 stout ventral spines apically; tibia pale, dark apically with 1 apical spine; tarsomere 1 without spine, 2 with 2 closely apposed apical spines, 3 without spine, 4 dark apically, 5 dark; $\mathrm{TR}_{\mathrm{I}}$ 2.5-2.8 (2.6). Midleg coxa, trochanter yellow; femur reddish yellow with dark apical patches on ventral, dorsal sides; tibia brownish yellow with dark bands on basal half, apical region bearing 2 closely apposed spines, tarsomeres 1 and 2 with 2 apical spines, other characters same as in foreleg; $\mathrm{TR}_{\mathrm{II}}$ 3.2-I3.70 (3.49). Hindleg coxa, trochanter yellowish with brown patches; femur reddish yellow with brown patches on dorsal side, apical region swollen; tibia darker with brown shades; tarsomere 1 bearing 1 basal spine and 1 apical spine, 2 with 1 apical spine, 3 without spine; 4 and 5 dark. $\mathrm{TR}_{\mathrm{III}} 2.89-3.5$ (3.10); claws subequal.

Abdomen. Pale yellow, in some with brown bands. Segment IV gradually widening, V-VI wide, VII narrow. Genitalia (Figs 1e, h). Tergite IX roughly rectangular posteriorly with 10 strong setae. Apicolateral process finely setose, short, stout, basally wide with blunt apex. Gonocoxite long, slender with 7-8 strong setae. Gonostylus elongate, covered with fine spicules, apical one-third dark with roughly fringed hook-like pointed tips. Aedeagus (Figs 1c, f) slender, subtriangular, well-defined anterior concavity, strongly curved, bifurcated, blunt ended basal arch, pointed posteromedial process projecting from base of tapered "U" shaped curvature giving rod-like appearance; parameres (Fig 1d) abutting basally but not fused, basal half directed laterally, bifid posterolaterally.

\section{Female $(n=4)$}

Head (Fig 2a). Yellowish brown. Vertex with 10-14 setae. Clypeus reddish yellow bearing 11-13 setae on each side. Eyes bare, weakly contiguous. Antenna yellowish (Fig 2e), with sparse Sch; flagellomeres 1-5 apically brown, basal one quarter pale, 1-8 flaskshaped, 6-8 darker than previous segments, 9-13 greyish brown, 10-13 longer bearing spines on each flagellomere, AR 1.10-1.25 (1.18). Palpus (Fig 2b) dark brown, third palpomere longest without sensory pit, with scattered 5 Sch, PR 3.2-4.5 (4.00). Mandible (Fig 2c) highly chitinised, broad basally with 10-12 teeth on inner surface. P/H 0.44-0.64 (0.52).

Thorax (Fig 2k). Same as male except larger sizes and numbers of thoracic spines.

Wing (Fig 21). Same as male except costa 2.76-2.92 (2.84) mm long, WL 3.00-3.24 (3.10) mm, WB 0.84-0.88 (0.86) mm. CR 0.90-0.94 (0.92).

Legs. Reddish yellow, densely setose. Foreleg coxa, trochanter yellowish; coxa with scattered setae; trochanter yellowish with two long transparent setae; femur pale armed with 1-5 stout apical spines; tibia pale with light brown apex, tibial comb with 28-32 
irregular little curved spines (Fig 2d); tarsomere paler than femur and tibia, tarsomere 1 without spine, 2 with two strong apical spines, 3 small, with no spine, 4 bilobed and two strongly bifid bearing a strong black spine (Fig $2 \mathrm{~h}$ ) and each with scattered long setae, 5 slightly curved ventrally with no ventral spine. $\mathrm{TR}_{\mathrm{I}} 2.30-2.75$ (2.51). Claw 0.12-0.13 $(0.12) \mathrm{mm}$ long nearly about length of tarsomere 5 , having strong, ventral blunt basal tooth (Fig 2h). Midleg coxa, trochanter yellowish, as in foreleg; trochanter with two long transparent setae; femur yellowish without ventral spine, dark marking at joint of trochanter and femur, brown apical band on dorsal side; tibia yellowish with broad brown basal band with a strong apical spine present, $\mathrm{TR}_{\mathrm{II}} 3.40-4.00$ (3.70); tarsomere pale, 1 with two strong apical spines, 2 with two apical spines, 3 smaller with no spine; 4, 5 and claws same as foreleg; claw 0.11-0.12 (0.11) mm long. Hindleg longer than fore and mid leg. Coxa, trochanter yellowish brown, trochanter with a pair of small transparent setae; femur swollen sub apically with dark apical brown; tibia pale brown with brown pigmentation on basal part continuing towards mid section with brown apex (Fig $2 \mathrm{~m}$ ). $\mathrm{TR}_{\mathrm{III}} 1.40-1.50$ (1.42); tarsomeres paler, 1 with a very strong spine and another weak one at base and apex bearing well-arranged palisade setae, 2 with a strong apical spine, 3 slightly darker with 2 strong apical spines, 4 with a pale basal and a simple apical spine, 5 with no spine. Claw single 0.40-0.42 (0.41) mm long with blunt internal basal tooth, 1.04 times longer than tarsomere 5 (Fig 2i); hind tibial comb composed of 11-13 spines (Fig 2g) and weak feather-like spur.

Abdomen. Pale yellowish brown sometimes with dark streak in lower portion, petiolate, vase-shaped with a few long lateral spines at upper side. Segments I-III longer, IV gradually widening, V-VII wide; tergite VIII pale, apical part hairy. Two functional spermathecae, more or less round, dark brown, larger one measuring $0.06 \mathrm{~mm}$ by $0.04-0.05$ (0.047) $\mathrm{mm}$; smaller one $0.05 \mathrm{~mm}$ by $0.04-0.05(0.042) \mathrm{mm}$. Third spermatheca dark brown, rudimentary (Fig 2f). Shape of sternite IX roughly rectangular with undulating posterior margin (Fig $2 \mathrm{j}$ ).

\section{Pupa and larva}

Unknown.

\section{Etymology}

The species is named after Professor SuIIT KUMAR DAS GUPTA in honour of his immense contribution to Indian Ceratopogonidae.

\section{Distribution and bionomics}

The species was collected in India (West Bengal state). Adult midges were collected from a bushy area using a light trap in the type locality. It was found in the northern plains of West Bengal, at an altitude of $58 \mathrm{~m}$ above sea level. 


\section{DISCUSSION}

Tetrabezzia pictipennis and T. dasguptai share quite a similar wing pigmentation, a reddish brown body and legs but differ in antennal colouration, which is white in $T$. pictipennis and reddish yellow with a brown apex in T. dasguptai; the scutellum is completely brown in T. pictipennis while it is yellowish in T. dasguptai. T. pictipennis has a black and shiny abdomen where segment 2 gradually widens and segments 3-5 are wide and segments 6-7 gradually taper, but in $T$. dasguptai the abdomen is light yellowish brown, except segments 4-7 sometimes with three almost parallel, dark chocolate brown bands, segments 2-3 are long, segment 4 gradually widening and 5-7 wide. The parameres are fused basally in $T$. pictipennis but just abutted basally in $T$. dasguptai with a more strongly clavate apex. In T. spinigera, on the other hand, the antenna is 14 segmented, the maxillary palpus is 4 segmented, the haltere brownish-red, the thorax smooth and glabrous, the abdomen barely curved and barely pubescent, with the $2^{\text {nd }}$ abdominal segment being the largest; this is quite unlike $T$. dasguptai. Our new species also has close similarities with $T$. africana. Both species share the same body colouration, arrangement of setae on the clypeus, setose legs, especially the fine hairs covering tarsomere 5 of the hind leg in the female, and basally joined parameres. Apart from these similarities, there are also some differences between them. In $T$. dasguptaia grey patch is present below the anal vein which touches both the vein and just the upper portion of the anal lobe; this feature is not present in T. africana.T. africana possesses a supra-alar region with 1-3 strong spine(s), a black postscutellum, and a dark patch on the hind leg femur in the female extending broadly in the basal two-thirds. In contrast, $T$. dasguptai has 1 strong spine in the supra-alar region, a pale reddish brown postscutellum, and an axe-like dark streak on the hind leg femur. In T. africana the gonostylus is wholly dark with long setae, whereas in $T$. dasguptai only the apical two-thirds is dark and covered with minute fine hairs. The shape and structure of the aedeagus and parameres are also different in both species. Three other Afrotropical species - T. diazi De MeIllon, 1961, T. soeroi (De MeIllon, 1942) and T. argentea InGRAM \& MACFIE, 1923 - have dark legs and an overall dark appearance, unlike T. dasguptai.

\section{KEY TO THE WORLD SPECIES OF TETRABEZZIA (FEMALE)}

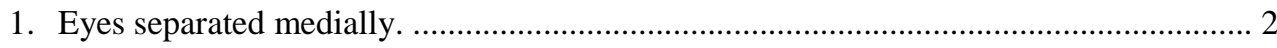

- Eyes contiguous medially, at least with $1-2$ ommatidia. ................................................ 3

2. Scutellum with more than two spines; apex of all femora and hind tibia dark brown and distal three-quarters light brown. T. diazi De MeILlon, 1961 (Africa) 
- Scutellum with two spines; all femora and hind tibia uniformly black.

T. soeroi (DE MEILLON, 1942) (Africa)

3. Legs dark brown; pigmentation restricted to $\mathrm{r}-\mathrm{m}$ cross vein and its surroundings. T. argentea INGRAM \& MACFIE, 1923 (Africa)

- Legs reddish yellow brown; pigmentation not restricted to r-m cross vein and its surroundings.

4. Thorax smooth,withoutsetae. ................................ T. spinigera (KIEFFER, 1914) (India)

- Thorax with setae. 5

5. Pigmentation absent under anal vein and present in cell $r_{3}$.

T. africana CLASTRIER, 1982 (Africa)

- Pigmentation present just under anal vein and absent in cell $r_{3}$. .. 6

6. Flagellomeres white; abdomen black and shiny. .. T. pictipennis (KIEFFER, 1913) (India)

- Flagellomeres reddish yellow basally, brown distally; abdomen pale brownish. T. dasguptai sp. n. (India)

\section{KEY TO THE WORLD SPECIES OF TETRABEZZIA (MALE)}

1. Aedeagus triangular; parameres fused at base. ..... T. pictipennis (KIEFFER, 1913) (India)

- Aedeagus subtriangular, parameres not fused at base ... 2

2. Middle of aedeagus enlarged, basal arch ended with hook-like apex; weak concavity between basal arms of parameres. T. africana CLASTRIER, 1982 (Africa)

- Middle of aedeagus not enlarged, basal arch ending in blunt apex; strong concavity between basal arms of parameres. T. dasguptai sp. n. (India)

\section{ACKNOWLEDGEMENTS}

We are indebted to Dr P. K. CHAUdhuRI, former Professor, Department of Zoology, University of Burdwan, for kindly going through the manuscript and rendering helpful suggestions. The authors sincerely thank Dr Art BORKENT and one anonymous reviewer for critically reviewing the manuscript with a view to its improvement. The authors express their thanks to the Head, Department of Zoology, The University of Burdwan and Principal, Balurghat College (Govt. sponsored), Balurghat, West Bengal, India, for the laboratory facilities. The financial assistance of the West Bengal Biodiversity Board, Government of West Bengal [No.703/3K(Bio)-1/2016], enabling us to carry out this work, is duly acknowledged. We are grateful to the Department of Forest, Govt. of West Bengal, for permission to carry out the fieldwork. 


\section{REFERENCES}

BORKENT A. 2016. World species of biting midges (Diptera: Ceratopogonidae). Internet: http://www.inhs.illinois.edu/research/ FLYTREE/Borkent.html

Borkent A., Spineldi G.R., Grogan W.L.J. 2009. Ceratopogonidae (Biting Midges, Purrujas). In: B.V. Brown, A. Borkent, J.M. Cumming, D.M. Wood, N.E. Woodley, M.A. Zumbado (eds.) Manual of Central American Diptera, vol. 1. NRC Research Press, Ottawa, Ontario, Canada, 407-435.

Clastrier J. 1982. Description d'une nouvelle espèce afrotropicale de Tetrabezzia (Diptera, Ceratopogonidae). Cahiers O.R.S.T.O.M., Série Entomologie Médicale et Parasitologie 20: $307-312$.

De MeIllon B., WiRTh W.W. 1991. The genera and subgenera (excluding Culicoides) of the Afrotropical biting midges (Diptera: Ceratopogonidae). Annals of the Natal Museum 32(1): 27-147.

KIEFFER J.J. 1913. Nouvelle etude sur les chironomides de l'Indian Museum de Calcutta. Records of the Indian Museum 9: 119-197, pls. 11-12.

KIEFFER J.J .1914. Quelques nouveaux chironomides des Indes. Records of the Indian Museum 10: 313-315.

KIEFFER J.J. 1917. Chironomides d'Amérique conservés au Musée National Hongrois de Budapest. Annales Historico-Naturales Musei Nationalis Hungarici 15: 292-364.

INGRAM A., MACFIE J.W.S. 1923. Notes of some African Ceratopogoninae. Bulletin of Entomological Research 14(1): 41-74.

WiRTH W.W., Marston N. 1968. A method for mounting small insects on microscope slides in Canada balsam. Annals of the Entomological Society of America 61(3): 783-784.

Received: 13 March 2018

Accepted: 20 April 2018 